\title{
Management of Congenital Epulis: A Case Report with Review of Literature
}

\author{
Heena Sarangal ${ }^{1}$, Ritu Namdev $^{2}$, Virendra Singh ${ }^{3}$, Anju Devi $^{4}$
}

\begin{abstract}
Congenital epulis (CE) is a rare congenital growth affecting the gingival mucosa of neonates. It is also known as Neumann's tumor. It is a benign growth seen frequently on the maxillary alveolus than the mandibular alveolus. It has a tendency of occurrence in the female is more than the male with a ratio of 10:1. This case report documents the presentation and management of congenital epulis present on the anterior maxillary alveolus in a three days old male patient treated with modified microdissection electrocautery needle.
\end{abstract}

Keywords: Congenital epulis, Congenital granular cell, Congenital granular epulis, Modified microdissection electrocautery needle, Neumann's tumor, Tumorcongenital granular epulis.

Journal of South Asian Association of Pediatric Dentistry (2018): 10.5005/jp-journals-10077-3014

\section{INTRODUCTION}

Congenital epulis (CE) is a rare neonatal benign congenital -growth of the newborn that is usually presented at birth as a mass arising from the alveolar mucosa'. It is three times more common in the maxillary alveolus than in mandible alveolus ${ }^{2}$. It has a tendency of occurrence in females than males with a ratio of 10:1 $1^{3}$. They are not associated with any other congenital malformations $s^{4,5}$. Multiple lesions are rare as compared to solitary lesions ${ }^{6}$. When the case is addressed at the time of birth, a multidisciplinary approach should be needed. In this paper, we present a case report of congenital epulis in a male infant and discuss its clinical features, histopathological findings, and surgical treatment.

\section{Case report}

A three days old male infant was reported to the Department of Pedodontics and Preventive Dentistry with a chief complaint of difficulty in feeding and weight loss due to the mass present on the upper front region of the oral cavity. On intraoral clinical examination pink color, pedunculated, smooth surfaced, firm consistency mass measuring $10 \times 12 \times 10 \mathrm{~mm}$ was present on the anterior maxillary alveolus (Fig. 1). There was no difficulty in respiration and no family history of congenital abnormalities.

However, there was difficulty in feeding, and the weight gain was not as proper as per the age. Ultrasound was done before planning treatment, but there were no remarkable findings in the report. A provisional diagnosis of congenital epulis was hypothesized and surgical removal was planned under local anesthesia. Hematological tests were within normal limits ( $\mathrm{Hb} 16.5$

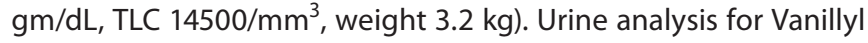
Mandelic Acid (VMA) was done and found to be negative hence melanotic neuroectodermal tumor of infancy (MNET) was ruled out.

The patient was appointed for surgery. He was 20 days old at the time of surgery. Mass was excised by a modified microdissection electrocautery needle (MMDN). Excised mass was sent for histopathological examination. There was only slight bleeding which did not require wound closure. The postoperative healing process was uneventful. Breastfeeding was allowed on the same day.

The gross examination of the specimen showed a pale white appearance measuring $1.2 \times 0.9 \times 1.3 \mathrm{~cm}$ (Fig. 2). Histopathologically hematoxylin and eosin $(\mathrm{H} \& \mathrm{E})$ stained section revealed overlying
${ }^{1}$ Postgradute Student, ${ }^{2,3} \mathrm{HOD},{ }^{4}$ Associate Professor

${ }^{1}$ Department of Pedodontics and Preventive Dentistry, Postgraduate Institute of Dental Sciences, Rohtak, Haryana, India

${ }^{2}$ Department of Pedodontics, Postgraduate Institute of Dental Sciences, Rohtak, Haryana, India

${ }^{3,4}$ Department of Oral and Maxillofacial Pathology, Postgraduate Institute of Dental Sciences, Rohtak, Haryana, India

Corresponding Author: Heena Sarangal, Postgradute Student, Department of Pedodontics and Preventive Dentistry, Postgraduate Institute of Dental Sciences, Rohtak, Haryana, India, Phone: +917973773171, e-mail: sarangalheena91@gmail.com

How to cite this article: Sarangal H, Namdev R et al. Management of Congenital Epulis: A Case Report with Review of Literature. J South Asian Assoc Pediatr Dent 2018;1(2):58-60.

Source of support: Nil

Conflict of interest: None

stratified squamous epithelium. Underlying connective tissue stroma showed closely packed large round, polyhedral cells with distinct borders, having abundant granular eosinophilic cytoplasm

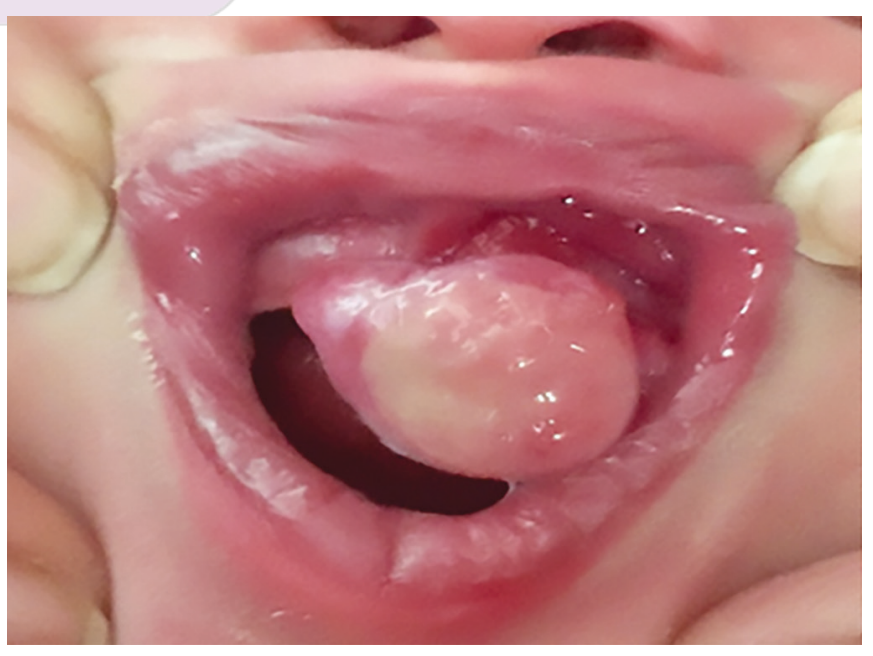

Fig. 1: Clinical picture showing congenital epulis

(0) The Author(s). 2019 Open Access This article is distributed under the terms of the Creative Commons Attribution 4.0 International License (http://creativecommons. org/licenses/by/4.0/), which permits unrestricted use, distribution, and non-commercial reproduction in any medium, provided you give appropriate credit to the original author(s) and the source, provide a link to the Creative Commons license, and indicate if changes were made. The Creative Commons Public Domain Dedication waiver (http://creativecommons.org/publicdomain/zero/1.0/) applies to the data made available in this article, unless otherwise stated. 


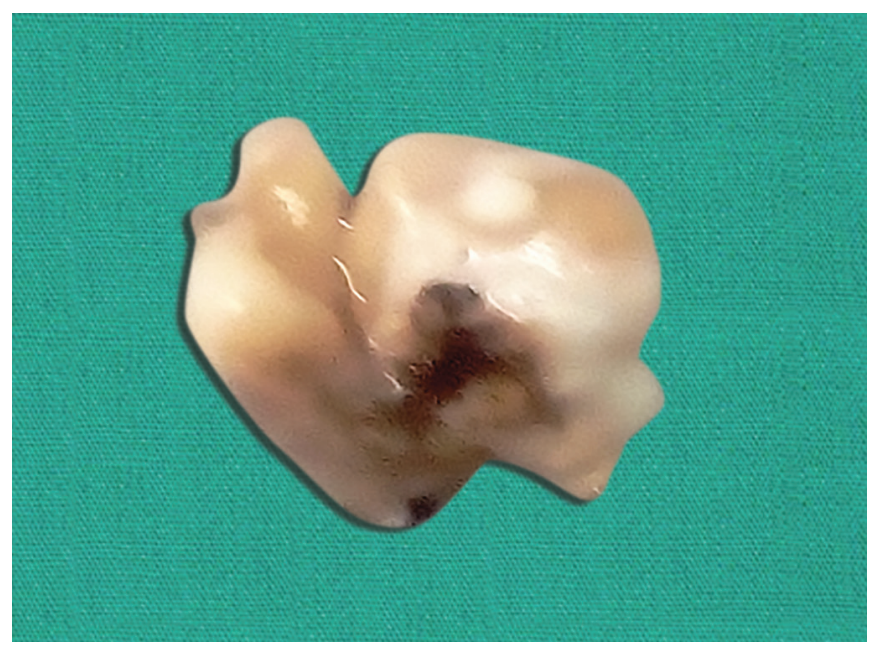

Fig. 2: Picture showing tissue

and eccentrically located vesicular nuclei, obliterating its normal architecture (Fig. 3). Histopathological diagnosis was consistent with the provisional diagnosis. So the final diagnosis of congenital epulis was established.

Follow up for three months did not show any recurrence and weight gain of the patient was age appropriate.

\section{Discussion}

Congenital epulis (CE) was first described by Neumann in 1871 , hence it is known as Neumann's tumor ${ }^{1}$, It is also known as congenital granular cell tumor, congenital granular epulis, congenital granular cell myoblastoma, congenital granular cell fibroblastoma².

The mass is usually present on the incisor-canine area of the maxillary alveolus and is also more common in maxilla than the mandible with a ratio of 3:1. However, it has also been described on the tongue $\mathrm{e}^{3}$. It is commonly seen in the neonates ${ }^{4}$. It is present as a well defined pedunculated mass with smooth or lobulated surfaced pink or red color, nonpainful mass, usually not associated with any other congenital abnormalities ${ }^{5}$. The size of the lesion varies from few $\mathrm{mm}$ to $9 \mathrm{~cm}$. which commonly interferes with the feeding and it may cause airway obstruction and it shows female predilection with a ratio of 10:1 (females: males) ${ }^{6}$. Several theories have been suggested such as myoblastic, odontogenic, neurogenic, fibroblastic, histiocytic and endocrinologic but no theory is able to define the etiology of the condition and is still controversial ${ }^{7,8}$. CE is usually an isolated finding; however, some cases are reported with polydactyly, goiter, triple $\mathrm{X}$ syndrome, maxillary hypoplasia, and neurofibromatosis. One case of polyhydramnios with CE also has been reported in the literature ${ }^{9}$. The occurrence is sporadical, and no familial tendencies have been described. CE usually is a solitary mass, but $10 \%$ of cases may occur as multiple lesions ${ }^{10}$.

These cases are mostly recognized at birth or just after birth except in cases where the size is small and the absence of symptoms. Prenatal diagnosis is difficult due to the absence of specific signs and also because epulis usually develops beyond the 22nd week of gestation. Fetal 3D ultrasound and MRI can provide the diagnosis by the 36th gestational week, thereby helping to plan in advance early multidisciplinary management. The diagnosis is usually made on the clinical features, MRI and

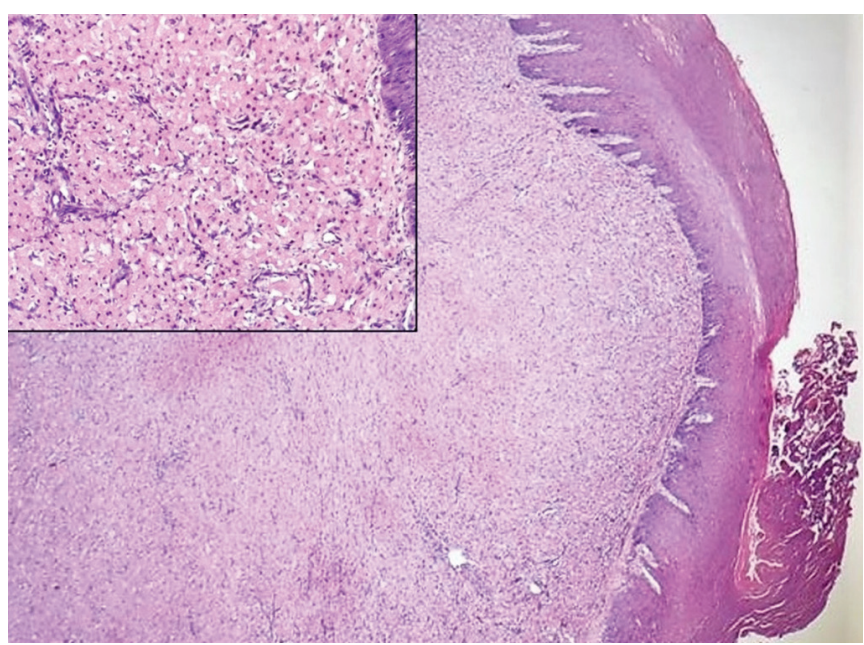

Fig. 3: Histopathological picture stained with $\mathrm{H}$ and $\mathrm{E}$ stain

ultrasound. The MRI is superior and useful than ultrasound ${ }^{1,2}$. Differential diagnosis of congenital epulis of newborn includes Epstein pearls, granular cell tumor, vascular malformation and neuroectodermal tumors of infancy ${ }^{3}$. In the case of the premaxilla, the differential diagnosis includes mucosal cyst of newborn and Melanotic Neuroectodermal Tumor of Infancy (MNET). Vanillyl Mandelic Acid (VMA) test is mandatory to exclude MNET, since CE on the one hand, does not change the level of VMA. Whereas in the case of MNET, high levels of VMA are common findings ${ }^{11}$.

Although it is benign and spontaneous regression has been reported related to the small thickness of the pedicle. There have been 8 case reports documented in the literature that showed spontaneous regression. Immediate surgical intervention is required because of the risk of the patient's life due to asphyxia. Literature shows no evidence of surgical excision affects the eruption of the teeth and the growth of the bone ${ }^{6}$. Excision can be done under local or general anesthesia. If the largest dimension of CE is less than $2 \mathrm{~cm}$ and the lesion does not interfere with the respiration and feeding, nonsurgical management of lesion is ought to be considered. Surgical excision using erbium, chromium: yttrium-scandium-gallium-garnet (Er, Cr: YSGG) and carbon dioxide laser has also been reported ${ }^{7}$.

Immunohistochemical studies show no reactivity of CE to S-100 protein, NGFR/p75, and inhibin-alpha ${ }^{7}$. Moreover CE cells do not react for laminin, as do the granular cells of granular cell tumor $(\mathrm{GCT})^{11}$. Furthermore, GCT reveals expression of S-100 protein, atypical of $C E^{12}$

Electrocautery is commonly used in such surgical procedures; however, it is not cost effective. In this case, the mass was excised with the help of modified microdissection needle (MMDN), For this modification, a standard needle of 21 gauge is separated from its hub using wire twister and taking care not to cause needle stick injury. The shaft of the needle is secured to the monopolar electrocautery tip by adapting it using an insulating tube sleeve. The insulating tubes can be customized by cutting a plastic feeding tube of various lengths. The tube allows for a snug fit of the needle, which means a lesser loss of power and secure placement of the needle with the cautery tip. The needle length and shape could be adjusted for different sites of surgery and the convenience of the operator (V. Singh and P. Kumar in 2018). It is very cost effective and works equally and efficiently for skin 
and scalp incisions. It works best at 10-15 W, lower power usually for infants and deeper tissue dissection. The needle shape and length could be adjusted according to the site of surgery and the convenience of the operator. The modification procedure requires only 2 to 4 minutes approximately ${ }^{13}$. Therefore authors suggest the use of MMDN considering its advantages and efficacy.

Histopathological examination shows thin squamous epithelium and underlying cell with large round, polyhedral cells with distinct borders, having abundant granular eosinophilic cytoplasm and eccentrically located vesicular nuclei with conspicuous nucleoli. Spindle cell epulis as a variant of CE has been reported in an 8-month-old child with histologically ovoid cells with vesicular nuclei and scant, nongranular eosinophilic cytoplasm ${ }^{14}$.

\section{ConCLUSION}

Congenital epulis (CE) may regress spontaneously, but immediate intervention is required if it is obstructing the airway passage and causing difficulty in feeding. Anesthetic modalities and surgical treatment plan should be done properly. Management of CE with MMDN needles proves to be safe, equal efficacy as compared to costly patented microdissection needle and cost-effective.

\section{References}

1. Bosanquet D, Roblin G. Congenital epulis: A Case Report and Estimation of Incidence. International Journal of Otolaryngology. 2009;2009:5080780.

2. Kumar RM, Bavle RM, Umashankar DN, Sharma R. Congenital epulis of the newborn. Journal of Oral and Maxillofacial Pathology. 2015;19(3):407-409.
3. Kupers AM, Andriessen P, Muriel JP. Congenital epulis of the jaw: a series of five cases and review of literature. Pediatr Surg Int. 2009; 25(2):207-210.

4. McGuire TP, Gomes PP, Freilich MM, Sandor GK. Congenital epulis: A Surprise in the Neonate. J Can Dent Assoc. 2006; 72(8):747-750.

5. Kannan SK, Rajesh R. Congenital epulis - congenital granular cell lesion: A case report. J Indian Soc Pedod Prev Dent. 2006Jun;24(2)104106.

6. Lee J, Kim U, Shin SH. Multiple congenital epulis of the newborn: A case report and literature review. J ped surg case reports. 2013;1:3233.

7. Aparna HG, Jayanth BS, Shashidara R, Jaishankar P. Congenital pulis in a newborn: A case report, immunoprofiling and review of literature. Ethiop J Health Sci. 2014;24(4):359-362.

8. Inan M, Yalcin O, Pul M. Congenital fibrous epulis in the Infant. Yonsei Medical Journal. 2002;43(5):675-677.

9. Ritwik P, Brannon RB, Musselman RJ. Spontaneous regression of congenital epulis a case report and review of literature. J Med Case Rep. 2010;4:331.

10. Nagpal R, Suryavanshi P, Malshe N, Godse A, Kalrao V. congenital epulis case report and literature review. Indian Journal of Neonatal Medicine and Research 2013;1(1):18-20.

11. Lee C, Hong S, Lim C, Chi J. Melanotic neuroectodermal tumor of infancy. J Korean Med Sci. 1986;1(1):63-67.

12. Damm DD, Cibull ML, Gissier RH, Neville BW, Bowden CM, Lehmann JE. Investigation into the histogenesis of congenital epulis of newborn. Oral Surg Oral Med Oral Pathol. 1993;76(2):205-212.

13. Singh V, Kumar P. Modified microdissection electrocautery needle. Natl J Maxillofac Surg. 2014;5(2):243-244.

14. Ottoman BAE. Diagnosis and management of congenital epulis of newborn: a rare case report and literarture review. International J Scientific Reports. 2015;1(1):80-82. 